\title{
Infectious Virus: Biophilia and Sustainable Museum Education Practices
}

\author{
AlmaDís Kristinsdóttir
}

\begin{abstract}
Museums offer significant learning experiences that contribute to sustainable societies and lifelong learning. However, museum education has historically been a field in flux, and a constant revitalization is needed. This paper examines Biophilia, created by artist and musician Björk, as a case-study to illustrate the potential of its pedagogical approach to affect sustainable museum learning practices. Biophilia inspires children to learn about sound, science, and nature through technology; it is an app-album that manifested itself in a museum context both as a concert venue and a multi-disciplinary experimental educational platform —ideal for museum learning. While the project was formally implemented in Iceland through high levels of inter-institutional collaboration, its theoretical relationship to museum education and critical pedagogy of place was overlooked. Using Biophilia's analogy of an 'infectious virus' and a futurist's framework of creativity and play, I ask: what can the field of museum education learn from Biophilia?
\end{abstract}

\section{Introduction: Viruses in the clouds}

Museums are 'educational powerhouses', full of potential for significant learning experiences meant to open doors to rich cultural experiences (DfE 2013; Hein 1998; Hooper-Greenhill 2007). ${ }^{1}$ Embedded within a larger learning landscape of public institutions, parks and cultural heritage sites, museums promote a holistic vision of informal learning practices ${ }^{2}$, where boundaries between disciplines are blurred and digital technologies are increasingly used to engage with content (Falk and Dierking 2013; Gibbs et al. 2007; Hohenstein and Moussouri 2018). Yet museums are not fully recognized as vibrant twenty-first century learning venues and sometimes viewed as problematic pedagogical sites that need to reorient themselves (Eisner and Dobbs 1986; Hooper-Greenhill 1991; King and Lord 2016; Semmel 2012). The museum's educational function is contested and several factors affect the professional conduct of museum educators ${ }^{3}$ including unclear role definitions and lack of learning theory (Hohenstein and Moussouri 2018; Nolan 2011). Museum educators comprised over $60 \%$ of museum workers who lost their jobs in a fairly recent recession (Kley 2009) and loss of funding for museum education services is evident in the UK, although 'core public-facing work' continues to be prioritized despite financial pressures. ${ }^{4}$ These factors attest to the inherent vulnerability of the profession (Kristinsdóttir 2017; Nolan 2011; Reeve and Woollard 2015). If museums as educational settings face a 'crisis' of becoming irrelevant, failing at encouraging lifelong learning and are absent in discussions about educational research - with their precarious educational function achieved through incidental learning (Gibbs et al. 2007; Janes 2009; Kristinsdóttir 2017; Nielsen 2015; Semmel 2012; Simon 2016; Vallance 2007)—-then what would revitalize museum education and bring the profession to a less precarious state?

In 2011, the Icelandic singer-songwriter and experimental artist Björk Guðmundsdóttir, released the world's first app-album Biophilia, a platform with an explicitly educational aim (Dibben 2011) described as a multimodal, inter-institutional collaboration (Husby 2016). The project invited audiences to explore the relationship between nature, technology, and music (Dibben 2013) and included custom-made musical instruments, internet-based content, workshops for children, and live performances (Dibben 2011). Björk worked with app developers, scientists, 
writers, inventors, musicians, artists, and museum professionals. ${ }^{5}$ Biophilia was awarded best science communication project in 2011 by EUPRIO, ${ }^{6}$ Björk received the Webby Artist of the Year award in $2012^{7}$ and a Grammy for design in $2013 .{ }^{8}$

This paper examines the pedagogical approach of Biophilia-an educational project in a museum context-as an epistemological contribution for reinvigorating the sustainable museum education practices that, according to Davies and Wilkinson (2008); Falk and Dierking (2013) and Koster (2012), can help museums to develop and maintain meaningful relationships with their communities and support the well-being of future generations. ${ }^{9}$ Biophilia thematically touches upon issues regarding creating a sustainable future, using education, creativity, innovation and cross-disciplinary thinking to engage children in learning (Hillgrén et al. 2016). The fields of museum education and environmental learning that Biophilia pertains to can be understood as organisms that are mutually supportive and beneficial, yet tend to exist in separate frameworks, but what would happen if one infected the other?

From 2015-2017, six interviews were conducted with project managers, all closely associated with the Biophilia project from the beginning. The findings presented here ${ }^{10}$ reiterate that Biophilia is not only about the app,$^{11}$ but more importantly about experiential learning. Attributed to Kolb (1984), experiential learning is a theory that draws together ideas from a number of well-known educational theories (as cited in Hohenstein and Moussouri 2018) and includes four processes: experiencing, reflecting, thinking and acting. Björk used similar processes, was inspired by museum learning and passionately driven to teach kids in a more creative and tactile manner. ${ }^{12}$

First, I will illustrate the educational format of the Biophilia concerts and their links to museums with Björk performing in the character of the 'frustrated music teacher' desiring change (Fenton and Strickland 2014; O'Connor 2014; Skinner 2016). ${ }^{13}$ Then I will trace the development of Biophilia Educational Project still utilized in Finland and Iceland with financial support through $2017 .{ }^{14}$

While the project was formally implemented in Iceland through a high level of interinstitutional collaboration, its theoretical relationship to museum education and a critical pedagogy of place was overlooked. I argue that Biophilia offers both theoretical and practical lessons that can reinvigorate sustainable museum education practices. On the one hand, museum education would benefit further from embracing creativity and play as forms of experiential learning, hybridity and technology, using the analogy of an 'infectious virus', a concept drawn from Biophilia. On the other hand, an examination of the limitations of Biophilia, the missed opportunities, showcases the structural and practical challenges that sustainable museum education faces,${ }^{15}$ including a lack of integration with formal education. Within the confines of this paper, I cannot discuss the pedagogical approach of all the museums involved, but a list of seventeen museums in nine countries that participated in Biophilia from 2011-2017 compiled for this research is provided in endnotes..$^{16} \mathrm{I}$ have selected a few examples to illustrate the potential of Biophilia's pedagogical approach to infect and affect sustainable museum learning practices.

\section{The educational zeal of Biophilia}

Biophilia ${ }^{17}$ means 'love of living things' and has been identified as a distinct category of motivation related to museum visits 'where one finds oneself relaxing and feeling a pleasant surge of energy' (Hohenstein and Moussouri 2018: 253). However, the definition used for the project is 'love of nature' (Fenton and Strickland 2014). Media celebrity Sir David Attenborough, one of Björk's many collaborators, opened the Biophilia concerts with his voice, connecting them to the pedagogical apparatus of nature documentaries (Tiainan et al. 2015). Björk gave a synopsis of her musical identities in an interview with Time magazine regarding her 2015 retrospective exhibition at New York City's MoMA, which also acquired Biophilia and recognized it as the first downloadable app in their permanent collection. ${ }^{18}$ In her synopsis, Björk explained that her teacher identity in Biophilia resembles 'a woman who has her head in the clouds', so she chose 'big orange hair' for her character who takes her class on an utopian journey through the galaxy and back to the tiniest organism, meeting nature with curiosity and using all senses (Halldórsson et al. 2015). Björk with her orange wig became a powerful visual reference to the 
natural world (Tiainen et al. 2015). Philosopher Timothy Morton, who contributed to Björk's MoMA catalogue, stated that there is a sense of 'ecological awareness' in her work emphasizing that 'everything is interconnected'. ${ }^{19}$ In the catalogue, Björk and Morton collaborated on defining her 'woman matriarch' vision of going forward to nature, not back (the opposite of the romantic nineteenth century notion) through the 'green techno internet age' (Morton 2015).

The Biophilia tour that preceded the Biophilia Educational Project lasted two years with 70 performances with three to four week residencies in most places. According to Björk, important inspirations for the project were her witnessing less privileged children participate in educational workshops at the New York Hall of Science, ${ }^{20}$ worldwide environmental issues, and the 2008 financial meltdown in Iceland (Mitchinson 2011). Because of the residency structure, a workshop teaching model for kids at museums became an evolving part of the project (Dibben 2011). ${ }^{21}$ Science museums were preferred both as sites for concerts and workshops, since their hands-on learning methods had close thematic links to the content explored in the app-album. ${ }^{22}$ On tour, the workshops utilized the Biophilia staff in between concerts, collaborating with local museums and schools (Husby 2016). ${ }^{23}$ In some instances, museums played a backdrop role as venues. At other times, they functioned as pedagogical partners in fulfilling the project's goals: to encourage young people's interest in creativity, natural sciences and technology (Gíslason and Bragadóttir 2017; Hillgrén et al. 2016) and turning traditional teaching methods on their head through creative play. ${ }^{24}$

The Biophilia educational workshops strengthened the enhancement of a learning 'ecosystem', a physical and virtual learning space that includes networks of people and support structures. ${ }^{25}$ Thus the concept of 'critical pedagogy of place' coined by Gruenewald (2003) was an important yet overlooked link to museum learning in Biophilia. ${ }^{26}$ Place-based education refers to 'pedagogy that seeks to connect learning to local ecological, cultural, and historical contexts' (Elfer 2011:2). It is an approach inspired by Dewey (1938) which advocates motivating students to engage with the local environment while participating in experiential learning (Hohenstein and Moussouri 2018). Place-based education is connected to critical pedagogy, experiential learning, contextual learning, problem-based learning, constructivism and outdoor and environmental education with place as a guiding construct (Gruenewald 2003). Although unexplored in the Biophilia literature, there is also an overlap between museum learning theory and the Italian pedagogy of Reggio Emilia (Malaguzzi 1988) described as 'progressive, childled, creativity-based approach' (Kirk 2012) where the environment is presented as the 'third teacher' ${ }^{27}$ The overlap is grounded in the pragmatic and social constructivist philosophies of learning (Hein 1998; Hein 2012; Kirk 2012). Eilean Hooper-Greenhill's concept of the 'postmuseum' is likewise helpful for understanding the Biophilia project's pedagogical strategy, and its connection to museum learning (2000). The 'post-museum' embraces informal learning, experiential modes of communication and use of media technology. Bruce (2006) found that popular culture views the twenty-first century museum as a hybrid, an interplay between the artefact and the potential of technology, shifting the focus from object to experience. A fusion of education and digital media is apparent in 'mediated museum communication' that looks towards a 'wider panoply of media, concepts and models' (Parry 2015: 17). One of the defining terms around digital learning is 'post-digital' which means that digital is the dominant thinking mode and simply a tool for engaging with the world (McKenzie 2015). Museum futurists see great potential for museums as expertise locations in immersive, experiential, hands-on learning-well suited to 'foster the twenty-first century skills of critical thinking, synthesis of information, innovation, creativity, teamwork and collaboration' in a learning ecosystem' ${ }^{28} \mathrm{~A}$ hybrid blend of 'digital' and 'non-digital' involvement as 'an embodied augmentation of one with the other' is yet another form of museum learning and public engagement (Parry 2013: 37).

Additionally, Biophilia's pedagogical approach is parallel to the multi-disciplinary approaches that encourage embodied, enactive, and immersive learning in museums (HooperGreenhill 2007); further, the approach resembles progressive museum education practices (Hein 2012), emphasizing participation and learning through experience-a perfect match for sustainable museum education practices, maintaining the social relevancy of museums (Simon 2016). However, both the 'post-museum' concept and the Biophilia project pose challenges to museums, since the direction of technology-based, experiential learning and creative play 
contradicts the conventional traditions of museums as contemplative places (Bruce 2006; Kristinsdóttir 2017). It is perhaps because of this challenge to conventionality and museum's 'inherent conservatism' (Janes 2013) that the connections between Biophilia and museum learning were unclear in the projects' execution.

An interesting 'side-project' to Biophilia was a partnership called the Nordic Knowledge Train, presented as 'a science communication outreach project' with the aim of 'exploring new methods in formal and informal education' (Gíslason and Bragadóttir 2017: 20). Biophilia was affiliated with the University of Iceland Science Centre (UniSci) which is strongly influenced by the educational apparatus of science museums, but focuses on science teaching in the University context. The Nordic Knowledge Train thus represents a solid connection of Biophilia to museum education thinking. The unclear ownership of Biophilia seems to have complicated its dissemination, minimizing the museum connection and encouraging stakeholders to follow their own agenda. The fairly common STEM or STEAM ${ }^{29}$ approach used in many science museums might have been useful for Biophilia to unify and clarify its focus across institutions, complementing school curriculum and lifelong learning in museums.

\section{Biophilia's 'infectious' pedagogical approach and the potential for museum education}

Museums have a long history of making collections and ideas relevant for visitors through an array of educational practices (Hein 1998; Hooper-Greenhill 1991; Nielsen 2015; Roberts 1997). Museum educators have a valuable presence in museums in their critical position to connect museums and communities ( $\mathrm{Ng}$ and Ware 2014; Nolan 2009). Biophilia foregrounds empowering change agent qualities for museum educators such as being proactive with small specifics to improve a situation (Hirsch 2000). However, the limited recognition and understanding of their work, both in research and practice (Tran and King 2007), leaves museum educator's profession periodically in a state of uncertainty, low status and vulnerability (Reeve and Woollard 2015; Roberts 1997; Rodéhn 2017; Vallance 2007). Education is inevitably political, especially in relation to critical, place-based and progressive pedagogy (Gruenewald 2003; Hein 2012). For example, the educational traditions of critical pedagogy and place-based education synthesized into a hybrid of a critical pedagogy of place insists that places outside of school or the 'local contexts of shared cultural politics' are experienced and interrogated by students and teachers as a part of the curriculum (Gruenewald 2003: 9). Similarly, Dewey's progressive education combines a 'particular pedagogy' using experiential methods counter to traditional lectures and promotes democratic practice as a 'specific political goal' (Hein 2012: 14). Museums are rooted in place ${ }^{30}$ and share political and cultural contexts through their educational activities. Biophilia enhances the idea of place through its theme and digital entity.

Björk had envisioned Biophilia as 'an inspiring and enabling thing' for children (Hooper 2013). Her idea initially manifested itself as 'some sort of a museum' (Dibben 2013) with sustainable characteristics and a 3D, physical experience. ${ }^{31}$ Each room in the museum was intended to represent one song, with interactive exhibits corresponding to the natural science subject matter addressed in the music (Dibben 2013). Instead of rooms in a museum, each song became an interactive app. Björk has always experimented with technology. Innovations occurring as Björk worked on Biophilia — especially the launch of Apple iPad in 2010 —changed the project's scope and shape..$^{32}$ In Biophilia, touchscreens became the interactive educational environment and functioned similar to a museum model with a focus on bringing people together in conversation through stories, art, and objects (Grant 2015). ${ }^{33}$ This function was not explicit in the Biophilia literature, although it may have been assumed, considering the project's integral connection to museum learning as presented in this paper.

The Biophilia Educational Project, as a Nordic collaboration, was hosted by the Icelandic Ministry of Education, Science and Culture, the City of Reykjavík, University of Iceland, and the Nordic Council of Ministers, from 2014-2016..$^{34}$ Iceland sought collaboration with the other four Nordic countries (Denmark, Finland, Norway and Sweden), as well as the Åland Islands, Faroe Islands, and Greenland. Local networks were set up in every participating country to implement and shape the project locally through steering committees. Each committee 
consisted of representatives from 'school authorities, a cultural institution and a science museum/university' (Elíasdóttir et al. 2016:6). ${ }^{35}$

The main objectives in the Nordic network were to promote innovation in schools through the development of educational methods, using cross-disciplinary approaches.

The teaching guidelines of Biophilia Educational Project acknowledge the porous fields of culture and education, emphasizing the transformative powers of 'infections' (Husby 2016: 61; Skinner 2016: 71). Halldórsson et al. (2015: 2) describe this as follows in Biophilia's official teaching guidelines:

Education, like art, music and love is a contested field. Opposed forces collide and infectious ideas invade the core of the operation, while a huge number of people seem to enter and leave without notice, like the dark matter of the universe. Biophilia forms part of one such force; or possibly maybe more an infection.

Biophilia has an app associated with every song. ${ }^{36}$ Virus, one of the ten song-apps, emphasizes symbiotic relationships—negative and positive (Halldórsson et al. 2015: 30). Viruses are usually seen as a negative thing, however the connection between the cell and the virus can also be seen as a 'symbiosis where two organisms live off each other' 37 In the Virus song-app, participants can flick the infectious agents away but in order to hear the whole song they have to let the central cell be 'attacked' (Hoffman 2012). ${ }^{38}$

Bryan Alexander, a futurist and educational researcher, was hired by the Icelandic government as a consultant to the Nordic Council of Ministers: Nordic Bioeconomy initiative (NordBio) where Biophilia was one of the main projects. NordBio recognized Biophilia's promotion of creativity as a research tool and an educational method apparent in the many explorative layers and levels of suggestions for teachers in each song-app connected to its subject matter regarding music, nature, relevant science and human elements. ${ }^{39}$ I would add, in light of the above discussion regarding museum learning, critical place-based education and child-led approaches. All the Biophilia elements are easily adapted to museum experiences on site and online. Alexander was a keynote speaker and conducted a workshop at the Biophilia closing conference ${ }^{40}$ where he presented a framework to educate for sustainability (Gíslason and Bragadóttir 2017). Alexander listed five principles to consider. A brief overview is presented here, examined in more detail below: 1) to change curriculum and pedagogy; 2) new literacies; 3) democratically engaged education; 4) commitment to 'openness' and 5) schools [or museums] as sustainable sites. ${ }^{41}$ To set the Biophilia 'virus' in motion and animate the informal platform of museum education, I adapt Alexander's framework to illustrate the relevance of Biophilia for sustainable museum education practices.

1) Biophilia is and has the potential to change curriculum both in the formal and informal education sector. Alexander addressed the lessons of Biophilia as important components towards a sustainability curriculum, emphasizing interdisciplinary teaching, creativity and play (Gíslason and Bragadóttir 2017).42 This aligns well with the main objectives presented by the Reykjavík Steering Group (RSG hereafter) where 'interdisciplinary studies and teaching' approach was considered highly successful in Iceland (Hilmarsdóttir et al. 2016: 16) although scant participation was clearly an impeding factor preventing proper evaluation..$^{43}$ Biophilia provided an intriguing digital environment to engage in collaborative, embodied, empowering, and interdisciplinary practices and explore unrelated phenomena infused with participatory emphasis (Skinner 2016). Professor Hargreaves ${ }^{44}$ observed that the collaborative teaching element in Biophilia is an important step towards change in curriculum and pedagogy (Ormarsson 2014).

2) Biophilia employed new literacies embedded in its pedagogical approach, specifically museum literacy ${ }^{45}$ and digital literacy. Hein (1998) defines 'museum literacy' as a framework for organizing educational activities. 'Museum literacy', is a broader term than 'museum education' and more useful in digital and network focused societies (Van Vliet 2012). Biophilia contributed with its explorative touchscreens 'window' as a digital educational platform, encouraging extensive collaboration between museum and school communities as well as fostering intergenerational communication within 
groups and families. Digital literacy refers to knowledge acquired through technology and involves resources, processing and communicating ${ }^{46}$ The crux of the Biophilia educational workshops was to encourage children to explore their own creativity through technology, increasing their digital literacy. Students became more 'active, creative, curious and had fun' with the apps (Elíasdóttir et al. 2016: 17). In the technically savvy society of Finland, one of the world leaders in effective education systems (Hargreaves and Fullan 2012), local managers of Biophilia stated that it was the 'perfect tool' for change with its multi-literacy emphasis (Auðunsdóttir 2016).

3) Biophilia exemplified democratic education by making the official teaching guidelines available online in seven languages (Halldórsson et al. 2015) although at the time this paper is written they are unfortunately no longer available. The educational framing of Biophilia is a statement of progressive pedagogy (Husby 2016) and reflects experiential museum education methods and democratic practices (Hein 2012). Democratic education requires collective responsibility, consciousness and action were attitudes, values and ethics are essential factors. ${ }^{47}$ Björk's concern for the environment in Biophilia is both important and relevant component of democratic education since museums are grounded in a sense of place (Janes 2013).

4) Openness distinguishes several aspects of Biophilia. It encourages students to transform and create their own meaning of the world with its interdisciplinary approach and high level of creativity. Biophilia's creative spark can ignite change in the form of a 'virus' perhaps turning traditional teaching methods on their head and opening up to unexpected possibilities. Within the apps, kids can create their own songs based on Björk's work-a generous feature of the project. The implementation process in Reykjavík, based on end-of-project reports, indicates that participants had indeed the flexibility to adjust the project 'beyond their organizational structure' and the parameters of the classroom (Hilmarsdóttir et al. 2016: 9). This factor supports that there is room for a theoretical relationship to museums. However, in practice, a paradox appeared in the oddly rigid structure of the workshops using only 'approved teachers' with Biophilia training as well as appointed expert scientists. This structure left no room for collaboration with informal learning environments. As a result, Biophilia was severely restricted and exclusive.

5) Biophilia as tool for education toward sustainability fits Alexander's suggestion that schools or, in this case, museums, should be such sites. ICOM's (2013) Codes of Ethics emphasizes that museums be of service to society and its development, and provide learning opportunities related to natural and cultural heritage. Björk's vision for Biophilia is similar to Emlyn Koster's vision for museums (2012): both media work as bridge-builders between various groups and common issues. Björk managed to entangle place-based qualities and museum education practices through her creative vision of connecting the educational workshops on tour to participating communities (including museums), offering and linking lessons regarding nature and culture in her app as a tool for education toward sustainability. This quality of the project has not been fully realized.

\section{Practical lessons and limitations of Biophilia}

Multiple sources of documents were analyzed for this case-study and key players were interviewed, revealing some practical lessons and limitations of the project. The Biophilia world-tour educational workshops created connections and collaborations with local museum educators. In practice, it proved more difficult for Biophilia to reside in museums for longer periods of time because of the demands and complexities of the project. The museum connection 'faded somewhat' as the project progressed. ${ }^{48}$ Usually the support and budget available at the museums was limited.

Initially, the educational framework of the workshops focused on 10-12 year olds, however there was considerable age variation in practice. As an example, the Children's Museum of 
Manhattan and the New York Public Library offered workshops for very young children and teenagers ${ }^{49}$ and the RSG involved children from four to 15 years old (Hilmarsdóttir et al. 2016). The Nordic network became even more flexible with the project's age target (Hillgrén et al. 2016) to finally engage school students of all ages, subjects, and disciplines (Elíasdóttir et al. 2016; Gíslason and Bragadóttir 2017).

One of the RSG's responsibilities was to organize workshops at the city's cultural organizations (Hilmarsdóttir et al. 2016). One such organization was the Reykjavík Art Museum (RAM), the only museum in Iceland that has been awarded the highest honor based on ICOM standards, specifically for their educational efforts. In January 2016 a statement placed above the museum's entrance read: 'The museum is a school: the artist learns how to express himself; the public learns how to make connections'. The statement was a part of an international exhibition called Back to the Sandbox: Art and Radical Pedagogy, an artwork by Luis Camnitzer, attempting to connect the traditions of reform and progressive pedagogy to the educational mission of the museum (Anděl 2016). RSG saw great potential for Biophilia in early stages of this exhibition, as its focus was on children, pedagogy and the present education system. ${ }^{50}$ Initially, Biophilia was to be integrated in the exhibition because of its pedagogical content and creativity. ${ }^{51}$ In practice, RAM treated the exhibition as any other, and did not create any specific educational opportunities relating to Biophilia. ${ }^{52}$ RAM initially viewed the project as an 'easy solution' to solve their educational provisions thinking that Björk with her ties to Iceland would make the practicalities of the project uncomplicated. The complexity of the inter-institutional collaboration however, proved to be a challenge. Biophilia ended up being a disconnected parallel project; neither the app nor the project methods were included in the exhibition and no mention of Biophilia at its opening. ${ }^{53}$ There is one reference to family workshops at RAM in the RSG's final report. Both RAM and RSG seemed to do their best to implement the project although a serious oversight was apparent in their lack of attempt of linking the formal and informal education systems within the city's and museum's organizational structures. No information was provided on how schools might integrate museum visits with Biophilia or engage in experimental learning. The teacher training courses offered to participants (Hilmarsdóttir et al. 2016) were not available to the city's museum educators until 2017, a missed opportunity to strengthen school and museum relationships. In conjunction with Back to the Sandbox: Art and Radical Pedagogy, two hour long workshops were offered to upper secondary schools and two seminars were organized to engage community members. Both initiatives were outsourced, a decision that suggests that RAM did not have the resources needed to collaborate effectively in a creative project like Biophilia. In an effort to connect Biophilia to RAM, Reykjavík teachers were invited to an exclusive guided tour of the exhibition. This was seen as way to 'nourish' the school community ${ }^{54}$ without any attempts to interrelate the pedagogical approach of the museum and Biophilia. RAM acted mainly as a physical venue hosting the seminars, but did not see a reason to participate in the community conversations of the outsourced events..$^{55}$ In June 2016 student's work related to Biophilia was exhibited at Reykjavik City Hall (Hilmarsdóttir et al. 2016) not RAM.

Indeed, the opportunities for the institutional integration of Biophilia's education potential seem to have been consistently overlooked. Although the 2015 Björk retrospective at MoMA generated many other museological questions ${ }^{56}$ beyond the scope of this paper, this particular disconnect is worth mentioning. There was a clear distinction between the app as an artwork on display and the educational aspect of the project. MoMA's own educational provisions and Biophilia were not synchronized. MoMAeducation staff viewed it as an external project belonging to an outside team. ${ }^{57}$ The Icelandic Ministry of Education, Science and Culture (MofESC) also considered the retrospective unrelated to the Biophilia Educational Project. It was 'just one small component', neither utilized on-site nor as a part of MoMA's digital educational offerings due to budget issues. ${ }^{58}$ In fact, museum learning was not considered at all when MofESC was developing the educational aspect of the project; yet, the project managers acknowledged museums as essential for the workshops on the world tour and as important meeting venues. Neither plans regarding potential workshops and a hands-on space for kids at MoMA nor arrangements for the exhibition to open at RAM materialized ${ }^{59}$

Regardless, Björk managed to build bridges 'between things that haven't had bridges between them before' (Gärkman 2016) ${ }^{60}$ Biophilia had the potential to become 'viral', spreading 
through unexpected networks. Perhaps the implementation process encouraged 'passive carriers' of the Biophilia virus, instead of actively 'spreading' the creative possibilities of learning.

\section{Concluding remarks: Sustainable Infections}

Initially, I asked what the field of museum education can learn from Biophilia? After familiarizing myself with the successes and limitations of practice, its project literature as well as interviewing key players in the implementation process, Biophilia has illuminated a bigger problem. The theoretical relationship to museum education and a critical pedagogy of place was completely overlooked as a model for informal learning practice despite the fact that museums as learning spaces were a major thematic concept in Biophilia. The process and scope of Biophilia cannot be replicated, but one of its lessons is thinking differently without being afraid of experimenting and using technology. Adopting alternative and 'post-digital' ways of thinking, Biophilia has potential beyond music and science. It is a powerhouse in itself, brimming with possibilities as a platform for bridging the gap between the formal and informal education systems, without limiting them in a dualistic approach, through creative teaching and learning methods, as well as exploring new learning environments (Gärkman 2016; King and Lord 2016). Biophilia opens up opportunities to restructure both the formal and informal education system, much like a virus enters a cell of another organism and replicates new viruses using material both from itself and the organism it has entered.

There is uncertainty and risk in embracing a 'virus'. However, interdisciplinary thinking across platforms could result in dynamic learning 'superpowers' fostering empathetic connections, both human and non-human, and transformations through pedagogy that is both socially and ecologically critical (Gruenewald 2003). Museums as places, on-site and online, offer significant learning experiences and projects like Biophilia can serve as a creative and empowering tool to interest children in the importance of cultural contexts. The museum education profession could also use some pedagogically transformative 'superpowers'.

Bryan Alexander's futurist framework harmonizes well with Biophilia. It brings museum educators a step closer to sustainable museum education practices although the theoretical relationship connecting museum education and a critical pedagogy of place needs to be explored further. One of the successful lessons of Biophilia is the importance of creativity and play. In the words of Alexander, who spoke at the end of Biophilia Nordic Council's tenure:

We need to heed the lesson of Biophilia. The curriculum and pedagogy has to embrace creativity and play. It is too easy for educators and academics to be dead serious. When we look at gaming we think oh that's great for kids, not for us. We are serious academics. We don't have fun. Fun is for other people. This is totally wrong. This is terrible pedagogically. This is the death of the spirit and this kills learning. We know that people learn by playing. By people I don't just mean children. I mean adults of all ages. We have to embrace the spirit of fun and creativity even in the face of horrors and terrible, nearly apocalyptic stresses, we have to hold on to that spirit of play and delight. ${ }^{61}$

Although this is a charming sentiment presented in the context of a NordBio conference, of which Biophilia was a part, there is a serious undertone of the importance of curiosity and experiential learning that has strong connections to museum learning (Hohenstein and Moussouri 2018). Museums need to take their educational role seriously to bring their 'public-facing services' to a less precarious state.

Björk described her hopes for the project connecting museum learning, children and nature in her disposition:

I would like to find a future international home for Biophilia — even though it's actually in an app. My dream originally was that it would be a museum or something, in Iceland, in nature, where kids could come and do courses. ${ }^{62}$

What museum educators can learn from Björk is her undying curiosity and willingness to experiment, using technology as a creative tool for learning and using the four processes of experiential learning: experiencing, reflecting, thinking and acting. The role of Björk in Biophilia, 
as the passionate teacher who encourages students to explore the interconnectedness of the world, is a powerful symbol of an educator as change agent that hopefully serves as an inspiring 'wake-up call' for museum educators. The orange wig is optional.

Received: 14 June 2018

Finally Accepted: 25 October 2018

\section{Notes}

1 AmericanAlliance of Museums, 'Building the Future of Education: Museums and the Learning Ecosystem' Center for the Future of Museums 2014. https://www.aam-us.org/2014/01/20/ building-the-future-of-education-museums-and-the-learning-ecosystem/ accessed 8 Oct. 2018

2 Informal learning occurs through family, social or civic life. It is cognitive, affective and bodily. Non-formal learning is more structured and organized. Learning opportunities designed by museums are mostly non-formal although 'informal learning' is used for both forms.

3 Museum educators, in this paper, refer to paid specialists who develop educational content and facilitate learning opportunities for museum guests of all ages.

4 Museum Association, Campaigns: museum funding. Museums in the UK 2018. https:// www.museumsassociation.org/campaigns/museum-funding/museums-in-the-uk accessed 4 Feb. 2018.

5 Curver Thoroddsen, artist, musician, educator, Björk's representative in the Reykjavík steering group, Assistant Engineer on the Biophilia album and Program Manager for the Biophilia educational workshops during the three year world tour, interview by author, digital recording, 6. Jan. 2017, Reykjavík, Iceland.

6 City of Reykjavík, 'Biophilia-smiðjurnar fá verðlaun sem besta vísindamiðlunarverkefnið' 2012. https://reykjavik.is/frettir/biophilia-smidjurnar-fa-verdlaun-sem-bestavisindamidlunarverkefnid accessed 8 Oct. 2018.

7 'Björk - Special Achievement - Artist of the Year', Webbyawards.com 2012. http:// webbyawards.com/winners/2012/special-achievement/special-achievement/artist-of-theyear/bjorkl, accessed 26 Feb. 2017.

8 'Björk wins grammy for Biophilia', Iceland Music 2013. https://icelandmusic.is/news/bjorkwins-grammy-for-biophilial, accessed 8 Oct. 2018.

9 Museum Association, 'Museums change lives: The impact of museums' 2017. https://www. museumsassociation.org/museums-change-lives/the-impact-of-museums, accessed 4 Feb. 2018.

10 The data was collected using a single case design and a descriptive case-study with multiple sources of evidence (Yin 2014). Interviews were digitally recorded, transcribed, coded and analyzed. Over one hundred documents were analyzed including book chapters, journaland newspaper articles, documentaries, teaching guides, thesis research, conference materials, reports and websites. Focus group session with Reykjavík participants was attended on 1 Sep. 2016.

11 Curver Thoroddsen, interview 6. January 2017.

12 Nick Neyland, 'Björk's Latest Experiment: Teaching Science', The Wall Street Journal 2012. http://blogs.wsj.com/metropolis/2012/01/26/bjorks-latest-experiment-teaching-science/, accessed 18 Feb. 2017. 
13 Kevin E. G. Perry, 'Interview: Bjork talks piracy, punk, Lady Gaga and Biophilia', Drowned in Sound 2011. http://drownedinsound.com/in depth/4143741-interview--bjork-talks-piracypunk-lady-gaga-and-biophilia, accessed 27 Jan. 2017; Nick Neyland, The Wall Street Journal 2012.

14 Auður Rán Porgeirsdóttir, Senior adviser, Icelandic MofESC, personal communication, 31 August 2017.

15 For a full treatment of these challenges see Kristinsdóttir 2017.

16 Children's Museum of Manhattan http://cmom.org/; I'ESPGG (Espace des Sciences Pierre-Gilles de Gennes) https://www.espgg.org in France, in collaboration with IRCAM - part of Centre Pompidou in Paris https://www.ircam.fr/\# and http://www.deuxieme-labo. $\underline{\mathrm{fr} /}$; Exploratorium in San Francisco https://www.exploratorium.edu/ ; HeK (Haus der electronischen künste Basel) Switzerland http://www.hek.ch/en/program/events-en/event/ biophilia/0/1443909600.html ; HEUREKA The Finnish Science Centre in Vantaa https:// www.heureka.fi/biophilia/?lang=en ; Jærmuseet in Southwest Norway with a travelling component called Science Circus https://www.jaermuseet.no/en/ ; Kunsthall Stavanger (a contemporary art institution) Norway https://kunsthallstavanger.no/en/ ; Miraikan, the National Museum of Emerging Science and Innovation in Tokyo, Japan https://www. miraikan.jst.go.jp/en/ ; MOCA The Museum of Contemporary Art, Los Angeles https:// www.moca.orgl; MoMA The Museum of Modern Art in New York City https://www.moma. org/ ; Museum of Science and Industry (MOSI) in Manchester msimanchester.org.uk ; Musée Curie in France http://musee.curie.fr/ ; New York Hall of Science https://nysci. org/ ; The Norwegian Museum of Science and Technology/Norsk tekn!sk museum http://www.tekniskmuseum.no/besok-oss/information-in-english ; Reykjavík Art Museum http://artmuseum.is/ ; Somerset House, London https://www.somersethouse.org.uk/ and Technichus Science Center in Härnösand, Sweden http://technichus.se/

17 The term was coined by Harvard biologist Edward O. Wilson (1984), whose hypothesis suggests that human beings have an innate affinity for the natural world.

18 Paola Antonelli, 'MoMA | Biophilia, the First App in MoMA's Collection', Moma.org 2014. https://www.moma.org/explore/inside out/2014/06/11/biophilia-the-first-app-in-momascollection/, accessed 8 Jan. 2017; Isaac Guzmán, 'Björk Is Your Tour Guide: An Exclusive TIME Interview for Her MoMA Retrospective' TIME 2015. http://time.com/3731906/bjorkmoma-retrospectivel, accessed 24 Jan. 2017.

19 Alex Blasdel, 'AA reckoning for our species": the philosopher prophet of the Anthropocene', The Guardian 2017. https://www.theguardian.com/world/2017/jun/15/timothy-mortonanthropocene-philosopher, accessed 15 June 2017.

20 Nick Neyland, The Wall Street Journal 2012.

21 David Fricke, 'Bjork Brings Her Engaging Spectacle to the New York Hall of Science', Rolling Stone 2012. http://www.rollingstone.com/music/news/bjork-brings-her-engagingspectacle-to-the-new-york-hall-of-science-20120206, accessed 7 Oct. 2018.

22 Curver Thoroddsen, interview 6. January 2017.

23 Kevin E. G. Perry, Drowned in Sound 2011; Curver Thoroddsen, interview 6. January 2017.

24 Arnfríður Sólrún Valdimarsdóttir and Auður Rán Porgeirsdóttir, 'NordBio-Biophilia', 2014 http://nordbio.org/projects/biophilia-2/ accessed 6 Oct. 2018

25 American Alliance of Museums, 2014. 
26 Decisions regarding Biophilia point to an awareness of a critical pedagogy of place although this discernment was not clearly stated in the interviews conducted for this paper.

27 Jeanne Vergeront, 'Exploring the Reggio - Museum Connection' Museum Notes [blog] 2013. https://museumnotes.blogspot.is/2013/04/exploring-reggio-museum-connection. html, accessed 8 Oct. 2018. stereogum.com/744502/stereogum-qa-bjork-talks-biophilia/franchises/interview/, accessed 8 Oct. 2018; Charlie Burton, 'In depth: How Björk's 'Biophilia' album fuses music with iPad apps', Wired UK 2011. http://www.wired.co.uk/article/music-nature-science, accessed 8 Oct. 2018.

Jefferson Hack and Björk, 'Bjork: On Music and Biophilia - The Sound of Nature', Wired 2013 [YouTube video]. https://www.youtube.com/watch?v=UTcy5c73ZZY, accessed 8 Oct. 2018.

33 Nora Grant, 'Pop-Up Museums in Santa Cruz', The Incluseum 2014. https://incluseum. com/2014/08/18/pop-up-museums-in-santa-cruzl, accessed 25 Feb. 2017.

34 Managers of the Biophilia Educational Project employed by the Icelandic Ministry of Education, Science and Culture, interview by author, digital recording, 9. April 2015, Reykjavík, Iceland.

35 Each country was required to teach Biophilia in minimum of three to five schools. Participants were eighty, three did not finish the project.

36 Scott Snibbe, 'björk: biophilia: tour app tutorial' YouTube 2012. https://www.youtube.com/ watch?v=n8c0x6dO2bg\&feature=youtu.be, accessed 8 Oct. 2018.

37 MofESC, 'Biophilia Educational Project' https://biophiliaeducational.org/apps/virus, accessed 5 Oct. 2018.

38 Scott Snibbe, 'Björk: Biophilia' [app suite, version 1.6] 2017. https://itunes.apple.com/us/ app/bj\%C3\%B6rk-biophilia/id434122935?mt=8, accessed 8 Oct. 2018.

39 MofESC, 'Biophilia Educational Project,Apps: Table of Elements' https://biophiliaeducational. org/ accessed 5 Oct. 2018.

40 The conference presented outcomes and evaluation of the eight participating Nordic countries in Reykjavík 3-5 October 2016. Future Biophilia workshop with Bryan Alexander was not open to researchers and no information is available about the 'new skills and content areas needed to best implement Biophilia principles in a changed future' claimed in the conference materials according to Auður Rán Porgeirsdóttir at Icelandic MofESC, personal communication, 31 August 2017.

41 Bryan Alexander, 'For a new settlement, or: how education can help us build sustainable societies', Minding the future: Bioeconomy in a changing Nordic reality, NordBio conference, 6 Oct. 2016. http://nordbio.org/about-nordbio/conference/speakers-and-moderators/ accessed 26 Jan. 2018. 

in Reykjavík 12-14 August 2014 where Biophilia was offered as a workshop. See: http:/l starfsthrounkennara.is/biophilia-education-project/

45 A term coined by Stapp (1984) implying that visitor's full access to museums depends on this form of literacy.

46 According to Alexander, digital literacy also involves creativity, critical thinking and evaluation, cultural and social understanding, collaboration; finding and selecting information; communicating effectively, practicing e-safety and having functional skills.

47 The Icelandic national curriculum guide for compulsory schools - with subject areas, 19. MofESC 2014. https://www.government.is/library/01-Ministries/Ministry-of-Education/ Curriculum/adalnrsk greinask ens 2014.pdf/, accessed 8 Oct. 2018. Museum of Manhattan to Launch a New Educational Programming Series' Cmom.org 2012. https://cmom.org/press/press-release-recording-artist-bjork-partners-with-new-york-publiclibrary-and-childrens-museum-of-manhattan-to-launch-a-new-educational-programmingseries/, accessed 10 Feb. 2018.

50 Manager of Children's Culture at Reykjavík's City department of Culture and Tourism and the department of Education and Youth; Head of the Biophilia Reykjavík steering group, interview by author, digital recording, 13 May 2016, Reykjavík, Iceland; Project Managers of Education and Events at Reykjavík Art Museum, interviewed by author, digital recording, 7 April 2016, Amsterdam, Netherlands via Skype to Reykjavík, Iceland. vulture.com/2015/03/momas-bjork-disaster.html, accessed 9 Jan. 2017.

57 Francesca Rosenberg, Director, Community, Access, and School Programs, Department of Education, The Museum of Modern Art, personal communication, 5 October 2017. Artnet 2015. https://news.artnet.com/art-world/moma-bjork-maybe-to-iceland-286738, accessed 7 Jan. 2017; Manager of Children's Culture and head of the Biophilia RSG, interview, 13 May 2016. 
Jefferson Hack and Björk, Wired 2013.

61 Bryan Alexander, NordBio conference, 6 Oct 2016.

62 Emily Mackay, 'Exclusive interview: The mistress of reinvention Björk remixes herself yet again', The Independent 2012. http://www.independent.co.uk/arts-entertainment/music/ features/exclusive-interview-the-mistress-of-reinvention-bj-rk-remixes-herself-yet-againfor-her-new-album-8320364.html, accessed 8 Oct. 2018.

\section{References}

Anděl, J. (2016) Back to the Sandbox: Art and Radical Pedagogy [booklet], Reykjavík: Reykjavík Art Museum.

Auðunsdóttir, S. D. (2016) ‘Biophilia: Fullkomið verkfæri fyrir breyttan skóla [Biophilia: The perfect tool for a changed school] Fréttatíminn, 8-12, Reykjavík: 8 October.

Bruce, C. (2006) 'Spectacle and Democracy: Experience Music Project as a Post-Museum', in Janet Marstine (ed) New Museum Theory and Practice: An Introduction, 129-151, Oxford: Blackwell Publishing.

Davies, M. and Wilkinson, H. (2008) Sustainability and Museums: Your Chance to Make a Difference, London: Museum Association.

Dewey, J. (1938) Experience and education: The Kappa Delta Pi Lecture Series, New York: Simon \& Schuster.

DfE, (2013) Cultural Education: A summary of programmes and opportunities, London: The DfE (Department for Education).

Dibben, N. (2013) 'Visualizing the App Album with Björk’s Biophilia' in Carol Vernallis, Amy Herzog and John Richardson (eds) The Oxford Handbook of Sound and Image in Digital Media, 682-706, Oxford: Oxford University Press.

Dibben, N. (2011) Björk Biophilia. 30 June-16 July Campfield Market Hall, MOSI, 4-5, Manchester: Manchester International Festival.

Eisner, E. and Dobbs, S. (1986) The Uncertain Profession: Observations on the State of Museum Education in Twenty American Art Museums, Santa Monica, California: The J. Paul Getty Trust.

Elfer, C. J. (2011) 'Place-based education: A review of historical precedents in theory and practice', unpublished Ph.D. thesis, Athens, Georgia: University of Georgia.

Elíasdóttir, Á., Hreinsdóttir, B. and Halldórsdóttir, B. (2016) The Biophilia Educational Project: Evaluation by Attentus, Reykjavík: Ministry of Education, Science and Culture.

Falk, J. and Dierking, L. (2013) The Museum Experience Revisited, Walnut Creek, California: Left Coast Press.

Fenton, N. and Strickland, P. [directors] (2014) Björk: Biophilia Live [film], London: Alexandra Palace Film Production.

Gärkman, L. (2016) Biophilia: Manuaali/Manual. Grankulla: biophiliaeducational.org.

Gibbs, K., Sani, M. and Thompson, J. (eds) (2007) Lifelong Learning in Museums. A European Handbook, Ferrara: EDISAl srl. 
Gíslason, S. and Bragadóttir, H. (eds) (2017) The Nordic Bioeconomy Initiative, NordBio. Final report. TemaNord 2017:526. Copenhagen: Nordic Council of Ministers.

Grant, N. (2015) 'Pop Up Museums: Participant-Created Ephemeral Exhibitions' Exhibitionist, Spring, 14-18.

Gruenewald, D. A. (2003) 'The Best of Both Worlds: A Critical Pedagogy of Place', Educational Researcher, 32 (4) 3-12.

Halldórsson, Á., Valdimarsdóttir, A. and Porgeirsdóttir, A. (2015) Learnteach: Teaching guidelines, Reykjavík: Ministry of Education, Science and Culture.

Hargreaves, A. and Fullan, M. (2012) Professional Capital: Transforming Teaching in Every School, London: Routledge.

Hein, G. (1998) Learning in the Museum, London: Routledge.

Hein, G. (2012) Progressive museum practice: John Dewey and Democracy, Walnut Creek, California: Left Coast Press.

Hillgrén, A., Bröckl, M. and Halonen, M. (2016) Nordic Best Practices: Relevant for UNEP $10 Y F P$ of Sustainable Consumption and Production, 33-36, Copenhagen: Nordic Council of Ministers.

Hilmarsdóttir, H., Bachmann, G., Pétursdóttir, S., Gestsson, S., Gísladóttir, E. and Thoroddsen, C. (2016), Final report for the Biophilia Educational Project 2014-2016, Reykjavík: The Biophilia Reykjavík Steering group.

Hirsch, J. S. (ed) (2000) The Change Agent: Selected Writings of Marcella Brenner, Washington, DC: The Museum Education Program, George Washington University.

Hoffman, J. (2012) 'Q\&A Scott Snibbe: Nature's digitizer', Nature, 485 (10 May) 172-173.

Hohenstein, J., and Moussouri, T. (2018) Museum Learning: Theory and Research as Tools for Enhancing Practice, London: Routledge.

Hooper, L. [director] (2013) When Björk Met Attenborough [film], London: Pulse Films and One Little Indian Records.

Hooper-Greenhill, E. (2007) Museums and Education: Purpose, Pedagogy, Performance, London: Routledge.

(2000) Museums and Interpretation of Visual Culture, London: Routledge.

(1991) Museum and gallery education, Leicester: Leicester University Press.

Husby, B. (2016) Exploring the Dark Matter of Björk's Biophilia Universe. A Study of the Biophilia Educational Project Based on Grounded Theory Methodology, unpublished Master of Music Education thesis, Bergen: Bergen University College.

ICOM, (2013) ICOM Code of Ethics for Museums, Paris: International Council of Museums.

Janes, R. (2013) The mindful museum: agents of change in a troubled world [presentation], Annual Conference of the British Columbia Museum Association, 25 October.

Janes, R. (2009) Museums in a troubled world: Renewal, Irrelevance or Collapse? London: Routledge.

King, B. and Lord, B. (eds) (2016) The manual of museum learning [second edition], Lanham, Maryland: Rowman \& Littlefield. 
Kirk, E. (2012) 'A School Trip for Reggio Emilia: Enhancing Child-led Creativity in Museums', in Rachael Jacobs (ed) Creative Engagements with Children: International Perspectives and Contexts, 133-141, [ebook]: Inter-disciplinary.net.

Kley, R. (2009) 'Recessionary Layoffs in Museum Education. Survey Results and Implications', Journal of Museum Education, 34 (2) 123-128.

Koster, E. (2012) 'The Relevant Museum. A Reflection on Sustainability', in Gail Anderson (ed) Reinventing the Museum. The Evolving Conversation on the Paradigm Shift [2nd ed], 202-211, Lanham, Maryland: AltaMira Press.

Kristinsdóttir, A. (2017) 'Toward sustainable museum education practices: confronting challenges and uncertainties' Museum Management and Curatorship, 32 (5) 424439.

Malaguzzi, L. (1988) Börn hafa hundrađ mál [Hundred Languages of Children], 35-69, [exhibition catalogue] Reykjavík: Menntamálaráðuneyti İslands [MofESC].

McKenzie, B. (2015) How can digital services enhance museum learning and partenrships with schools?, London: Flow Associates.

Mitchinson, A. (2011) 'Q\&A Björk: Digital diva', Nature, 477 (29 Sept) 537.

Morton, T. (2015) 'This huge sunlit abyss from the future right there next to you...' in James Merry (ed) Björk: archives IV, 49-72, London: Thames \& Hudson.

Ng, W. and S. M. Ware (2014) 'Excellence and Equity? A Reflection on the Diversification of Museums' in Jodi Boyd Acuff and Laura Evans (eds) Multiculturalism in Art Museums Today, 37-57, London: Rowman \& Littlefield.

Nielsen, J. (2015) 'The relevant museum: defining relevance in museological practices', Museum Management and Curatorship, 30 (5) 364-378.

Nolan, T. R. (2011) 'The Leadership Practice of Museum Educators', unpublished Ed.D. thesis in Educational Leadership, Chicago, Illinois: National College of Education, National-Louis University.

Nolan, T. R. (2009) 'The Museum Educator Crisis', Journal of Museum Education, 34 (2) $117-121$.

O'Connor, J. [director] (2014) Biophilia at Miraikan. [DVD] Tokyo: Alexandra Palace Film Production.

Ormarsson, O. P. (2014) ‘Kennsla metin að verðleikum’ [Valued teaching] Morgunblaðið, 14, Reykjavík: 31 August.

Parry, R. (2015) 'Prospecting postdigital museum communication' in Museum Communication: Practices and Perspectives: position papers, 16-18, Copenhagen: Royal Danish Academy of Sciences and Letters.

Parry, R. (2013) 'The End of the Beginning: Normativitity in the Postdigital Museum' in Sandra Dudley and Conal McCarthy (eds) Museum Worlds: Advances in Research 1, 24-39, New York: Berghahn Books.

Reeve, J. and Woollard V. (2015) 'Learning, Education, and Public Programs in Museums and Galleries.' In Conal McCarthy (ed) The International Handbooks of Museum Studies: Museum Practice, 551-575, Chichester, West Sussex: Wiley-Blackwell. 
Roberts, L. C. (1997) From Knowledge to Narrative. Washington and London: Smithsonian Institution Press.

Rodéhn, C. (2017) 'The job that no one wants to do? Museum educators' articulations about guided tours', Museum \& Society, 15 (1) 1-15.

Semmel, M. (2012) 'An opportune moment. Museums in the National Conversation on Early Learning', Journal of Museum Education, 37 (1) 17-28.

Simon, N. (2016) The Art of Relevance. Santa Cruz, California: Museum 2.0.

Skinner, R. (2016) Biophilia-að hugsa út fyrir boxið og fara á flug [Biophilia-to think outside the box and take off, unpublished MA in Art Education thesis Reykjavík: Iceland Academy of the Arts.

Stapp, C. (1984) ‘Defining museum literacy’ Roundtable Reports, 9 (1) 3-4.

Tiainen, M., Kontturi, K. and Hongisto, I. (2015) 'Framing, Following, Middling Towards Methodologies of Relational Materialities' Cultural Studies Review, 21 (2) 14-46.

Tran, L.U. and H. King (2007) 'The Professionalization of Museum Educators: The Case in Science Museums' Museum Management and Curatorship 22 (2) 131-149.

Vallance, E. (2007) 'Museums and cultural centers', in Liora Bresler (ed) International handbook of research in arts education, 672-677, Dordrecht: Springer.

Van Vliet, H. (2012) 'Museum literacy: why some things need nurturing', in Stella Chryssoulaki, Alexandra Bounia and Despina Andriopoulou (eds) Museum Education and New Media, ICOM Education 23, 69-78, Piraeus: Ministry of Education and Religious Affairs, Culture and Sports.

Yin, R. K. (2014) Case Study Research: Design and Methods, [5 ${ }^{\text {th }}$ edition] Los Angeles, California: Sage.

\section{AlmaDís Kristinsdóttir}

Manager of Museum Learning (Communication and Education)

Reykjavik City Museum

Grandagarður 8

101 Reykjavík

Iceland

alma.dis.kristinsdottir@reykjavik.is

+354 -411-6351

http://borgarsogusafn.is/en 